\title{
Bullying: Fenomena Gunung Es di Dunia Pendidikan
}

Meita Dhamayanti

Departemen Ilmu Kesehatan Anak Rumah Sakit Hasan Sadikin Fakultas Kedokteran Universitas Padjadjaran, Bandung

Bullying merupakan masalah universal yang dapat menjadi ancaman serius bagi kesehatan fisik dan emosional pada anak dan remaja. Masalah bullying saat ini menjadi sorotan karena dapat memengaruhi kualitas hidup anak dan remaja secara signifikan, serta memiliki implikasi jangka panjang terhadap proses adaptasi saat mereka dewasa. Bullying di Indonesia sudah memasuki tahap memprihatinkan karena cukup banyak orang menganggap bahwa bullying yang dialami atau dilakukan sebagi tindakan yang wajar. Untuk itu tenaga kesehatan khususnya dokter spesialis anak harus memahami jenis, dampak bullying pada kesehatan fisik dan mental, deteksi dini, tata laksana, dan pencegahan bullying, serta peran dokter anak pada perilaku bullying. Sari Pediatri 2021;23(1):67-74

Kata kunci: bullying, fisik, emosi, anak, remaja

\section{Bullying: Iceberg Phenomenon in Education}

Meita Dhamayanti

Bullying is a universal problem that can be a serious threat to physical and emotional well-being of children and adolescents. Recently, bullying has become an issue since its significant impact on children and adolescent's quality of life, and its long-term implication towards adaptation process when they become an adult. In Indonesia, bullying has entered the stage of concern because a lot of people believe that bullying is a normal tradition. Therefore, health care workers, especially pediatrician should understand the type and impact of bullying on physical and mental health, early detection, management, and prevention of bullying, as well as their role in bullying Sari Pediatri 2021;23(1):67-74

Keyword: bullying, physical, emotional, children, adolescents

Alamat korespondensi: Meita Dhamayanti. Departemen Ilmu Kesehatan Anak RS Hasan Sadikin, Fakultas Kedokteran Universitas Padjadjaran Jl Pasteur no 38 Bandung, Email: meita.dhamayanti@unpad.ac.id 
$\mathrm{F}$ enomena perilaku bullying merupakan fenomena gunung es, telah menarik perhatian para ilmuwan, pendidik, dan pembuat kebijakan selama lebih dari tiga dekade di sebagian besar negara-negara di dunia. ${ }^{1}$ Perilaku bullying di Indonesia sudah memasuki tahap memprihatinkan. Bahkan para peserta didik dalam berbagai tingkatan menganggap bahwa bullying yang dialami atau yang dilakukan sebagai tindakan yang wajar. ${ }^{2}$ Bullying dapat menimbulkan dampak negatif terhadap pelaku, korban, dan saksi. Dampak terbesar pada korban bullying berupa gangguan psikosomatik dan psikososial. Strategi dalam penanganan bullying memerlukan pendekatan holistik yang melibatkan guru, orangtua, murid, pekerja sosial, dan dokter. Peranan dokter anak dalam permasalahan bullying antara lain mengidentifikasi pasien berisiko, menasihati keluarga, dan mendukung implementasi program anti-bullying di sekolah. ${ }^{2,3}$ Mayoritas guru dan orangtua siswa cenderung tidak mengadukan tindakan bullying di sekolah karena khawatir akan menjadi pihak yang disalahkan. ${ }^{4,7}$

\section{Definisi Bullying}

Bullying merupakan sebuah kata serapan dari bahasa Inggris yang hingga saat ini masih sulit dicarikan padanan kata yang tepat dalam bahasa Indonesia. Selama ini bullying diartikan sebagai tindakan kekerasan, penindasan, atau intimidasi. Arti kata bullying merujuk pada Kamus Besar Bahasa Indonesia edisi ke-5 adalah perundungan, kata rundung memiliki arti suatu perlakuan yang mengganggu, mengusik terus-menerus dan juga menyusahkan. ${ }^{5}$

Definisi bullying pertama kali digambarkan oleh profesor psikologi asal Norwegia, Dr. Dan Olweus, "perintis" dalam penelitian bullying., Formulasi awal mengenai definisi bullying yaitu "... negative actions on the part of one or more other student (.... Aksi negatif yang dilakukan kepada satu atau lebih murid lainnya)', seperti: ${ }^{4}(1)$ mengatakan hal yang tidak menyenangkan atau memanggil seseorang dengan julukan yang buruk (2) mengabaikan atau mengucilkan seseorang dari suatu kelompok karena suatu tujuan (3)memukul, menendang, menjegal atau menyakiti orang lain secara fisik (4) mengatakan kebohongan atau rumor yang keliru mengenai seseorang atau membuat siswa lain tidak menyukai seseorang dan hal-hal semacamnya.
Berdasarkan formulasi tersebut dapat disimpulkan bahwa perilaku bullying merupakan tindakan negatif secara fisik, verbal, atau relasional yang a) memiliki maksud yang tidak baik, b) menyebabkan penderitaan bagi korban, c) dilakukan berulang-ulang, dan d) adanya ketidakseimbangan kekuatan antara pelaku dan korban.

\section{Prevalensi Bullying}

Penelitian International Center for Research on Women (ICRW) menunjukkan $84 \%$ anak Indonesia mengalami bullying di sekolah. Angka kasus kekerasan di sekolah di Indonesia lebih tinggi dari Vietnam (79\%), Nepal (79\%), Kamboja (73\%), dan Pakistan (43\%). ${ }^{7}$ Survei yang dilakukan United Nations International Children`s Emergency Fund (UNICEF) sebanyak 50\% siswa berusia 13-15 tahun di Indonesia mengalami bullying di sekolah. Hasil survei ini bahkan dianggap sebagai salah satu angka tertinggi di dunia. ${ }^{8}$

Komisi Perlindungan Anak Indonesia (KPAI) dalam kurun waktu tahun 2011 hingga 2016 menemukan 253 dari 23.000 kasus kekerasan fisik dan psikis terhadap anak, dikategorikan sebagai kasus bullying. Dari 253 kasus tersebut 122 laporan dari anak yang menjadi korban dan 131 laporan dari anak yang menjadi pelaku. Data KPAI menunjukkan angka korban bullying dari tahun 2011 hingga 2014 mengalami peningkatan 2,8 kali, sebesar 56 kasus pada tahun 2011 dan 159 pada tahun 2014, sedangkan anak sebagai pelaku bullying meningkat 2,3 kali dari tahun 2011 hingga 2016. ${ }^{9}$

Penelitian pada salah satu sekolah dasar negeri di Jakarta menunjukkan prevalensi bullying sebesar 89,7\% dengan proporsi terbesar adalah kelompok korban sekaligus pelaku yaitu $46,1 \% .^{10}$

\section{Lingkaran Bullying}

Tindakan bullying cenderung melibatkan tiga kelompok siswa yang berbeda, di antaranya pelaku bully (bullies), korban (victim), dan saksi (bystander)..$^{4,6,12}$

\section{Pelaku/bullies}

Bullies adalah seseorang dengan kekuatan sosial dan/ atau fisik yang berulang kali memilih orang lain atau sekelompok orang dengan maksud untuk menimbulkan bahaya atau rasa ketidaknyamanan. Bullies cenderung 
memiliki karakteristik kuat secara fisik, impulsif, pemarah, agresif, tidak takut, pemaksa, percaya diri, dan kurang empati terhadap korban-korban mereka. Mereka memiliki kepribadian yang agresif dan termotivasi oleh kekuatan dan keinginan untuk mendominasi orang lain. ${ }^{4}$ Agresif bullies cenderung merupakan sesorang yang populer, kemudian semakin lama menjadi semakin tidak disukai karena seiring dengan bertambahnya usia seseorang, mereka menjadi lebih mampu berpikir kritis tentang teman sebaya dan kriteria pemimpin. ${ }^{12}$

\section{Korban/victims}

Bullies tidak secara acak menyerang korban-korban mereka, sebaliknya mereka menargetkan subkelompok khusus orang yang sering menjadi korban selama beberapa tahun. Korban pasif merupkan kelompok terbesar korban bullying dan tidak secara langsung memprovokasi para bullies. Mereka anti sosial, sering tampak cemas, depresi, takut, dan memiliki konsep diri yang sangat buruk. Jika dibandingkan dengan teman sebayanya, korban pasif memiliki lebih sedikit teman, cenderung merasa kesepian dan sedih, serta tampak lebih gugup pada situasi baru. Kumpulan gejala ini menjadikan mereka target yang menarik bagi bullies., ${ }^{412}$ Pada awalnya korban akan menanggapi perilaku bullying dengan menangis, menarik diri, dan marah, selanjutnya akan muncul reaksi mencoba menghindari dan melarikan diri dari situasi intimidasi (misalnya, tidak hadir di sekolah, melarikan diri dari rumah). ${ }^{12}$

\section{Saksi/bystanders}

Sebagian besar orang termasuk dalam kategori bystander. ${ }^{4,12}$ Kelompok ini adalah semua orang, selain bulliers dan korban, yang hadir selama insiden bullying. Bystander adalah sesorang yang ikut mengamati aksi bullying; sebagai saksi, mereka mungkin dapat mengabaikan, mendukung tindakan bullying, atau membela korban. Bystander dapat menampilkan pola perilaku yang berbeda selama insiden bullying; perilaku ini mewakili sikapnya terhadap masalah bullying (misalnya, positif, acuh tak acuh, atau negatif) serta tindakan yang mungkin mereka ambil selama insiden yang sebenarnya.

\section{Jenis dan Bentuk Bullying}

Beberapa literatur membagi tindakan bullying berupa langsung dan tidak langsung. Bullying langsung adalah serangan yang relatif terbuka pada korban yang bersifat fisik dan/ atau verbal. Bullying tidak langsung lebih halus dan lebih sulit untuk dideteksi, tetapi melibatkan satu atau lebih bentuk agresi relasional, termasuk isolasi sosial melalui penyingkiran yang disengaja, menyebarkan desas-desus untuk mencemarkan nama atau reputasi seseorang, membuat wajah atau gerakan cabul di belakang seseorang, dan memanipulasi pertemanan atau hubungan lainnya., 2,4,6,11

Berdasarkan bentuk bullying dikategorikan ke dalam empat jenis, yaitu intimidasi fisik, bullying verbal, pengucilan sosial, dan pemerasan. ${ }^{4}$ Bullying fisik mengacu pada agresi fisik yang nyata seperti menampar, mendorong, menendang, dan meludah. Verbal bullying, yang mengacu pada agresi verbal terang-terangan, termasuk panggilan nama, menggoda, menghina, dan pernyataan yang mengancam. Pengucilan sosial mengacu pada merusak hubungan rekan sebaya atau status sosial, menyebarkan desas-desus, mengabaikan kehadiran korban, mengancam orang lain untuk tidak bermain dengan korban, atau mengarahkan tatapan mengancam atau mengintimidasi terhadap korban. Pemerasan adalah meminta uang atau properti. Beberapa tahun terakhir, seiring kemajuan dalam teknologi informasi membuat cyberbullying menjadi tantangan baru karena mudah dilakukan namun sulit untuk dituntut ke jalur hukum. ${ }^{6,12}$

\section{Sekolah sebagai Wadah Bullying}

Banyak tempat di sekolah diperkirakan sebagai tempat yang tidak aman oleh siswa oleh karena ketakutan akan perilaku bullying, termasuk kekerasan verbal, dan infrastruktur yang tidak memadai seperti toilet sekolah. Pelecehan, kurang tanggapan, dan adanya hukuman oleh guru sebagai bentuk disiplin merupakan beberapa faktor yang turut berkontribusi terhadap rasa tidak aman di sekolah. ${ }^{7}$

Bullying terjadi pada situasi saat korban tidak memiliki 'kekuatan' terhadap kelompoknya. Situasi ini dapat terjadi pada anak-anak di ruang kelas sekolah atau di rumah dengan saudara kandung, sehingga diibaratkan anak seperti terpaksa 'dikurung' dengan orang lain. Bullies akan berusaha untuk mengerahkan kekuatan mereka dengan semua anak dengan tujuan untuk membangun jejaring sosial atau hierarki. Mereka 
yang memiliki reaksi emosional (misalnya, menangis, melarikan diri, marah) dan tidak memiliki siapa-siapa untuk membela mereka, adalah target bagi bullies. Bullies dapat membuat orang lain untuk bergabung (tertawa, menggoda, memukul, menyebarkan rumor) sebagai bystander. ${ }^{11}$

\section{Dampak Bullying pada Anak}

Tindakan bullying memiliki efek yang merugikan tidak hanya bagi korban, tetapi juga pada bullies dan bystanders. ${ }^{6}$ Dampak yang timbul dapat berupa trauma fisik dan psikologis; dari intrapersonal ke interpersonal; dan dari jangka pendek hingga panjang. ${ }^{11}$ Para bullies berisiko memiliki rasa empati yang rendah terhadap orang lain sehingga mereka tidak peka terhadap bullying, dan menjadikan bullying sebagai bagian dari kehidupan normal mereka. Mereka lebih menikmati kepuasan perilaku agresif daripada kegiatan akademis sehingga lebih cenderung mengalami putus sekolah dan terlibat dalam kelompok, kenakalan, dan perilaku antisosial. ${ }^{11}$ Mereka mungkin mengalami kesulitan dalam menjaga hubungan interpersonal yang intim dan sehat, membina rumah tangga, dan dapat menjadi pasangan atau orangtua yang kasar. Efek jangka panjang yang mungkin terjadi juga dapat berupa peningkatan risiko depresi dan bunuh diri. ${ }^{6,7,11}$

Bagi korban bullying dapat menimbulkan efek luas yang dapat bertahan hingga dewasa dan mengganggu fungsi emosional, mental, psikologis, fisik, sosial, dan akademik. Korban bullying selama masa kanakkanak memiliki risiko lebih besar mengalami depresi, sifat cemas yang berlebihan, fobia sosial, rendah diri, sering kesepian, dan gagal dalam mempertahankan hubungan. ${ }^{6,13}$

Bystanders juga dapat mengalami dampak negatif dari tindakan bullying. Siswa yang mengamati tindakan bullying merasa tidak berdaya, gelisah, dan tertekan. Mereka sering memendam rasa bersalah karena tidak membantu korban, marah terhadap diri sendiri dan ke pelaku, serta rasa takut menjadi sasaran selanjutnya. Mereka mungkin juga merasa tidak aman di sekolah dan menjadi lalai di kelas karena perhatian mereka diarahkan untuk menghindari perilaku bullying. Efekefek ini dapat terbawa ke masa dewasa, berupa rasa ketidakmampuan dalam memecahkan masalah secara tersurat, pandangan terdistorsi tentang tanggung jawab pribadi, desensitisasi terhadap tindakan antisosial, dan difusi batas-batas pada perilaku yang dapat diterima. ${ }^{6,12}$

\section{Dampak bullying pada sistem neurologis}

Paparan tindakan bullying yang berat dan berlangsung lama telah terbukti berhubungan dengan masalah psikologis, seperti rasa rendah diri, kecemasan, dan depresi, Gangguan fisiologis yang berhubungan dengan depresi atau gangguan stres pasca trauma (post traumatic stress disorder/PTSD) akan terlihat pada korban bullying kronis. ${ }^{13}$ Pajanan terhadap stres yang berlangsung lama dapat mengganggu aksis hipotalamus-pituitary-adrenal (HPA). Penelitian pada hewan menunjukkan bukti peningkatan hiperkortisolisme basal dan tumpulnya respon HPA terhadap stres sosial pada subjek yang dikalahkan secara sosial. Pada manusia, pajanan stres yang lama dapat menyebabkan masalah psikologis berupa gangguan irama sirkadian dan peningkatan kadar basal kortisol. Anak-anak korban bullying menunjukkan tingkat kortisol yang lebih rendah di siang hari dibandingkan dengan kontrol (yang tidak di-bully), meskipun perubahan aktivitas kortisol (baik tingkat basal atau reaktivitas akut) akibat stres kronis masih belum terlalu jelas karena beberapa penelitian lain menunjukkan hasil yang berbeda-beda. ${ }^{13}$

Sekresi kortisol oleh korteks adrenal diatur oleh hipotalamus dan hipofisis anterior. Hormon adrenoko rtikotropik (ACTH) dari hipofisis anterior merangsang korteks adrenal untuk mengeluarkan kortisol. ${ }^{13,14}$

Pada orang normal segera setelah terpajan stressor akan terjadi peningkatan kortisol sebagai bentuk kompensasi tubuh. Pada awalnya amygdala menentukan ancaman atau situasi yang bisa menyebabkan stres. Sinyal kemudian dikirimkan ke hypotalamus sehingga disekresikannya corticotrophin releasing factor (CRF) dan menstimuli kelenjar pituitari untuk menyekresikan adenocorticotropin hormone $(\mathrm{ACTH})$ yang mengaktifkan korteks adrenal untuk mensekresi glukokortikoid terutama kortisol. Setelah pajanan stres berakhir maka kadar kortisol kembali ke tingkat basal. Tingkat kortisol dalam darah bervariasi sepanjang hari. Pada pagi hari, kortisol berada pada tingkat paling tinggi karena membantu tubuh untuk bangun dan menyediakan energi di siang hari, kemudian tingkat kortisol semakin menurun dan mencapai titik terendah setelah tengah malam. ${ }^{13,14}$ 
Sebuah meta-analisis terbaru memberikan ringkasan kompleksitas hubungan antara stres kronis, respons HPA, dan faktor yang memengaruhinya. Terkait dengan bullying, menunjukkan pajanan stres kronis mengakibatkan kadar kortisol siang hari lebih tinggi. Jika stresor dianggap tidak terkendali maka siklus kortisol harian menjadi tinggi secara terus-menerus, seperti pada pasien PTSD yang cenderung memiliki kadar kortisol tinggi sepanjang hari. Mayoritas subjek penelitian tersebut menunjukkan respons tingkat kortisol yang rendah terhadap tes stresor menggunakan deksametason, orang yang depresi menunjukkan tingkat kortisol yang lebih tinggi setelah tes yang artinya mereka kurang sensitif terhadap pengaruh eksternal yang memengaruhi sumbu HPA. ${ }^{13}$

Penelitian menunjukkan perbedaan jenis kelamin dalam respon stres bahwa rata-rata kortisol pria dan respon tekanan darah terhadap stres lebih jelas, sementara wanita menunjukkan respons detak jantung yang lebih besar daripada pria. ${ }^{14,15}$

Bullying juga secara diferensial dapat memengaruhi proses inflamasi kronis dan masalah kesehatan yang berhubungan dengannya, serta dapat bertahan hingga dewasa. Peningkatan kadar protein C-reaktif (CRP) yang berlangsung lama sebagai penanda inflamasi sistemik dalam tubuh, dapat meningkatkan risiko penyakit kardiovaskular, gangguan metabolisme dan masalah kesehatan mental seperti depresi. Pemeriksaan laboratorium pada darah korban bullying menunjukkan bahwa tingkat CRP meningkat dengan seringnya mereka mendapat perlakuan bullying. Tes darah yang dilakukan pada korban bullying setelah mereka mencapai usia 19 dan 21 tahun mengungkapkan bahwa mereka yang di-bully ketika anak-anak memiliki tingkat CRP dua kali lebih tinggi daripada bulliers, sementara bulliers memiliki tingkat CRP lebih rendah dibandingkan mereka yang bukan atau korban (Gambar 1). ${ }^{11}$ Kadar rata-rata protein c-reaktif (CRP) yang telah disesuaikan pada remaja $(\mathrm{mg} / \mathrm{l})$ berdasarkan status bullying. Nilainilai tersebut disesuaikan dengan kadar baseline CRP dan juga kovariat yang berkaitan dengan CRP lainnya.

Efek bullying di sekolah dapat berlangsung lama sehingga trauma psikologis dapat jauh lebih dalam dan berlangsung selama bertahun-tahun setelah kejadian. Rendahnya kepercayaan diri adalah salah satu gangguan mental yang paling rusak. Korban bullying sering merasa sangat tidak berdaya, tidak mempercayai orang dan bentuk kontak sosial apapun. Hal ini dapat membuat sangat sulit bagi korban untuk menjalin jaringan dan bekerja dengan tim. Mereka cenderung bersifat antisosial dan menjadi pecandu kerja untuk menghindari kontak sosial sebanyak mungkin. Kehilangan rasa percaya diri ini dapat memiliki dampak negatif yang besar terhadap kemampuan seseorang untuk menjadi sukses dalam hidup, terutama dalam hal mencoba untuk mendapatkan pekerjaan dengan gaji lebih baik, mendapatkan promosi atau menjadi kompetitif. ${ }^{16}$

Dampak yang paling terlihat dan dramatis dari korban bullying adalah tindakan bunuh diri. Bunuh diri sering kali berawal dari kesedihan dan depresi, merasa tidak ada yang bisa dipercaya dan sendiri sehingga

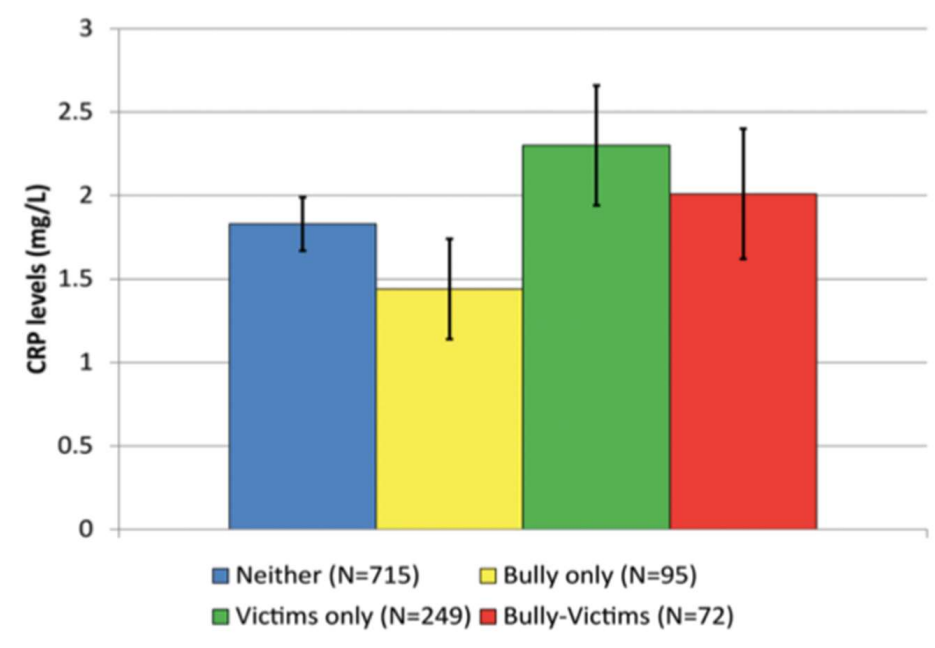

Gambar 1. Kadar CRP pada remaja korban bullying dibanding yang tidak (Sumber: Wolke 
muncul anggapan bahwa bunuh diri tampaknya menjadi satu-satunya cara untuk menghentikan rasa sakit. Bunuh diri sering terjadi setelah berbulan-bulan dan bahkan bertahun-tahun menerima perlakuan bullying, serta seringkali terjadi ketika menerima ejekan sosial dan rasa malu yang ekstrim., ${ }^{45,16}$ Pikiran bunuh diri umum terjadi pada anak-anak yang depresi, dan perilaku bullying telah menyebabkan banyak kasus bunuh diri di kalangan remaja. ${ }^{4,7}$ Tindakan bunuh diri sebagai konsekuensi dari bullying di sekolah sering berbeda berdasarkan jenis kelamin. Perempuan lebih rentan untuk melakukan bunuh diri secara diam-diam dan meninggalkan catatan dan pesan mengenai fakta tentang semua rasa sakit yang mereka derita, namun anak laki-laki lebih rentan untuk melakukan tindakan impulsif dan merusak sehingga menyebabkan bahaya bagi siapa saja yang menyerupai bulliers, sebelum mereka melakukan tindakan bunuh diri. ${ }^{14,15}$

\section{Prestasi akademik yang buruk}

Penelitian menunjukkan bahwa korban penindasan yang terus-menerus cenderung kurang berprestasi di sekolah. Sebuah studi tahun 2005 oleh University of California in Los Angeles (UCLA) mengamati sekelompok siswa sekolah menengah selama periode tiga tahun dan menemukan adanya korelasi langsung antara bullying dan performa akademis yang buruk pada siswa. Penelitian tersebut menunjukkan siswa yang mengalami tingkat bullying tinggi selama tiga tahun memiliki nilai yang jauh lebih rendah daripada mereka yang mengalami tingkat bullying yang rendah atau tidak dibully sama sekali, mereka yang menderita efek bullying umumnya tidak termotivasi untuk belajar. ${ }^{17}$ Tindakan bullying dan korbannya memengaruhi proses kegiatan pendidikan dan angka ketidakhadiran di sekolah. Di Inggris, lebih dari 16.000 anak muda berusia 11-15 tahun diperkirakan tidak hadir di sekolah negeri karena bullying sebagai alasan utama. ${ }^{18}$

\section{Deteksi Dini Bullying}

Beberapa kuesioner yang dapat digunakan untuk skrining perilaku bullying antara lain School Bullying Questionnaire (SBQ), Multidimentional Peer Victimization Scale (MPVS), Olweus Bullying
Questionnaire (OBQ). Kuesioner yang sering digunakan dan sudah terstandarisasi adalah OBQ. ${ }^{19}$

Deteksi dini perilaku bullying dengan observasi perubahan perilaku, emosi, dan prestasi sekolahnya, serta pendekatan (bicara dengan anak dan remaja seperti temannya). Beberapa tanda dapat dikenali seperti perubahan perilaku seperti susah makan, terlalu banyak makan, sulit tidur, mimpi buruk, mengompol, menangis tanpa sebab, kurang bertanggung jawab dan disiplin, cenderung impulsif, cenderung menentang peraturan, dan adanya perilaku agresi seperti merasa lebih berkuasa atau kuat, menyalahkan orang lain. ${ }^{20}$

\section{Tata Laksana Bullying}

Pada tata laksana mengatasi masalah bullying harus melibatkan orang tua murid dan sekolah, kebijaksanaan yang dibuat harus dilakukan baik di rumah maupun di sekolah. Terapi ditujukan pada kedua pihak, baik bulliers maupun korban. Tatalaksana perilaku bullying harus dilakukan secara komprehensif dan intensif. ${ }^{20}$

\section{Peran orang tua di rumah}

Berbicara dengan lembut pada anak, jadi pendengar yang baik dan jangan memberikan respon negatif dalam bentuk apapun (seperti marah, rasa tidak senang, komentar kasar). Beri pengertian pada anak dengan bahasa yang mudah dimengerti bahwa bila masalah ini dibiarkan akan dapat berulang pada orang lain dan akan menjadi masalah yang berkepanjangan. Beri pengertian bahwa suatu bentuk pertemanan adalah saling mendukung satu sama lainnya, bukan saling menjatuhkan atau saling menyakiti. Kondisikan suatu bentuk tata krama/kebiasaan yang baik di rumah sebagai contoh. Beri dorongan pada anak untuk menceritakan bila dia mengalami perilaku bullying. ${ }^{20}$

\section{Peran guru di sekolah}

Guru menerapkan peraturan di sekolah, adakan hukuman bagi bullies, membuat komunikasi yang baik antara murid-orangtua-guru. Sekolah membuat sesi konseling untuk semua pihak, baik bullies maupun korban. ${ }^{20}$ 
Tabel 1. Faktor risiko dan protektif terhadap perilaku bullying diberbagai tingkat

\begin{tabular}{lll}
\hline & Faktor risiko & Faktor protektif \\
\hline Individual & Konsep diri yang rendah & Rasa percaya diri yang tinggi \\
& $\begin{array}{l}\text { Keterbatasan fisik } \\
\text { Keterbatasan dalam kemampuan bersosialisasi } \\
\text { Keluarga }\end{array}$ & Kemampuan bersosialisasi yang baik \\
& $\begin{array}{l}\text { Perilaku agresif dini } \\
\text { Disiplin otoriter } \\
\text { Rendahnya supervisi orangtua }\end{array}$ & $\begin{array}{l}\text { Komunikasi efektif dengan orangtua } \\
\text { Sekolah }\end{array}$ \\
& $\begin{array}{l}\text { Kekerasan dalam rumah tangga } \\
\text { Sekolah yang overcrowded }\end{array}$ & Orangtua terlibat dalam kehidupan sekolah \\
& $\begin{array}{l}\text { Iklim persaingan yang tidak sehat di sekolah } \\
\text { Tetangga }\end{array}$ & Orientasi belajar \\
\hline Kekerasan dalam kelompok & Rekan sebaya yang dapat diteladani \\
\hline
\end{tabular}
Sumber: Tsitsika $\mathrm{AK}^{6}$

\section{Pencegahan Bullying}

Sebagian besar penelitian menyebutkan bahwa bullying merupakan fenomena multifaktorial yang dipengaruhi oleh faktor-faktor yang terkait dengan individu, keluarga, sekolah, dan tingkat komunitas yang lebih luas. Tabel 1 menggambarkan faktor-faktor yang paling umum dijumpai sebagai risiko atau faktor protektif terhadap insiden bullying. ${ }^{6}$

Identifikasi berbagai risiko dan faktor pelindung harus dipertimbangkan sebagai pedoman untuk pengembangan program anti-intimidasi yang efektif. Program Olweus Bullying Prevention Programme/OBPP di Norwegia dan program anti-intimidasi KiVa di Finlandia telah diterapkan di sekolah, kelas, dan tingkat individu yang melibatkan orang tua dan masyarakat untuk mencegah perilaku bullying. Tujuan dari program ini adalah mengurangi masalah bullying yang ada di kalangan siswa, mencegah perkembangan masalah bullying baru, dan mencapai hubungan teman sebaya yang lebih baik di sekolah. ${ }^{6}$

\section{Kesimpulan}

Bullying merupakan istilah 'payung' untuk berbagai interaksi verbal, psikologis, fisik, dan kekerasan. Bullying didefinisikan sebagai tindakan negatif secara fisik, verbal, atau relasional yang a) memiliki maksud yang tidak bersahabat, b) menyebabkan penderitaan bagi korban, c) berulang-ulang, dan d) adanya ketidakseimbangan kekuatan antara pelaku dan korban.
Bullying di Indonesia sudah memasuki tahap memprihatinkan karena cukup banyak siswa yang menganggap bahwa bullying yang dialami atau yang dilakukan sebagi tindakan yang wajar. Banyak guru dan orangtua siswa yang cenderung tidak mengadukan tindakan bullying di sekolah karena kekhawatiran akan menjadi pihak yang disalahkan. Bullying dapat menimbulkan dampak negatif terhadap pelaku dan korban. Dampak terbesar dialami oleh korban bullying, yaitu gangguan psikosomatik dan psikososial. Strategi dalam penanganan bullying memerlukan pendekatan holistik yang melibatkan guru, orangtua, murid, pekerja sosial, dan dokter. Dokter anak memiliki peran penting dalam permasalahan bullying, antara lain, mengidentifikasi pasien berisiko, menasihati keluarga, dan mendukung implementasi program anti-bullying di sekolah.

\section{Ucapan Terima Kasih}

Penulis mengucapkan terima kasih dan penghargaan kepada Citra Cesilia yang telah memberikan inspirasi, ide dan bantuan penulisan artikel ini.

\section{Daftar pustaka}

1. Ttofi MM, Farrington DP. Effectiveness of school-based programs to reduce bullying: a systematic and meta-analytic review. J Exp Criminol 2011;7:27-56.

2. Lyznicki JM, Mccaffree MA., Robinowitz CB. Childhood bullying: implication for physicians. Am Fam Physician 
2004;70:1723-30.

3. Vanderbilt D. Bullying. Dalam: Steven Parker, Barry Zuckerman, Marilyn Augustyn, penyunting. Developmental and Behavioral Pediatrics. Edisi ke-2. Philadelphia: Lippincott;2005.h.141-5.

4. Olweus D. Bullying at school: what we know and what we can do. Malden, MA: Wiley-Blackwell; 1993.

5. Kamus Besar Bahasa Indonesia. Arti kata perundungan [Internet]. Indonesia: Kamus Besar Bahasa Indonesia. 2017. Diakses pada 2 April 2018. Didapat dari: https://kbbi.web.id/rundung.

6. Tsitsika AK, Barlou E, Andrie E, dkk. Bullying behaviors in children and adolescents: "an ongoing story". Front Pub Health 2014;2:1-4.

7. International Center for Research on Woman. Are schools safe and equal places for girls and boys in asia? Thailand: ICRW; 2015.

8. The United Nations Children`s Found. Laporan tahunan Indonesia 2015. New York: Unicef; 2015.

9. Komisi Perlindungan Anak Indonesia. KPAI: Kasus bullying dan pendidikan karakter [Internet]. Indonesia: Komisi Perlindungan Anak Indonesia. 2014. Diakses pada 2 April 2018. Didapat dari: http://www.kpai.go.id/beritalkpai-kasusbullying-dan-pendidikan-karakter/.

10. Soedjatmiko, Nurhamzah W, Maureen A, Wiguna T. Gambaran bullying dan hubungannya dengan masalah emosi dan perilaku pada anak sekolah dasar. Sari Pediatri 2013;15:174-80.
11. Wolke D, Lereya ST. Long-term effect of bullying. Arch Dis Child 2015;100:879-85.

12. Tsang SKM, Hui EKP, Law BCM. Bystander position taking in school bullying: the role of positive identity, self-efficacy, and self-determination. Scientific World J 2011;11:2278-86.

13. Hamilton LD, Newman ML, Delville CL, Delville Y. Physiological stress response of young adults exposed to bullying during adolescence. Physiol Behav 2008;95:617-24.

14. Teicher MH, Samson JA, Sheu YS, dkk. Hurtful words: association of exposure to peer verbal abuse with elevated psychiatric symptom scores and corpus callosum abnormalities. Am J Psychiatry 2010;167:1464-71.

15. Parker G, Brotchie H. Gender differences in depression. Inl Rev Psychiatry. 2010;22:429-36.

16. Rigby K. Consequences of bullying in schools. Can J Psychiatry 2003;48:583-90.

17. University of California in Los Angeles. Victims of bullying suffer academically as well, UCLA psychologist report. California: UCLA. Diakses pada 7 April 2018. Didapat dari http://newsroom. ucla.edu/releases/victims-of-bullying-suffer-academically-168220.

18. Brown V, Clery E, Ferguson C. Estimating the prevalence of young people absent from school due to bullying. Nat Centre Soc Res 2011;1:1-61.

19. Olweus D. Olweus bullying questionnaire standard school report 2015. Norwegia: Hazelden Publishing: 2015.

20. Surilena. Perilaku bullying (perundungan) pada anak dan remaja. CDK-236 2016;43:35-8. 